\title{
EL OJO DE LA AGUJA
}

Para Claudia,

que nunca está por las tardes

Los amigos se han ido

uno por uno

por el ojo de la aguja

también los hilos de las conversaciones

el denso tejido de la amistad

Se han ido las nubes

y los vientos

el ruido de las piedras en los ríos

el canto del ave

la risa de mi hija

Las palabras se han quedado

exhaustas de sentido

la palabra casa por ejemplo

en la que me pierdo en sus pasillos

en sus habitaciones vacías

en sus paredes sin eco

Tu recuerdo

ya no sé dónde está

lo busco bajo las sábanas

en el olor de tu ropa

en los ceniceros

agobiados de colillas 
Todos se han ido

poco a poco

uno por uno

en silencio

también mi calle se va

con todas sus casas

y sus jardines

y los ladridos de sus perros

Ya no escucho

la voz de mi abuela en mi oído

no siento la dulce caricia

de sus arrugas

en mi rostro

Ya no queda nada

Sólo tengo frente a mí

en este otoño frío

el inquietante ojo de la aguja

\section{EL LOCO GENOVÉS}

Para Julián Meza

El barco zarpó

rumbo a Las Indias

-eso dijiste-,

pero no estabas seguro. 